www.jmscr.igmpublication.org

Impact Factor 5.244

Index Copernicus Value: 83.27

ISSN (e)-2347-176x ISSN (p) 2455-0450

crossref DOI: _http://dx.doi.org/10.18535/jmscr/v4i9.64

\author{
Journal Of Medical Science And Clinical Research \\ IGM Publication \\ An official Publication of IGM Publication
}

\title{
A Study of Serum Uric acid levels as a Prognostic Marker in Acute Myocardial Infarction
}

\author{
Authors \\ Dr Anu Daber ${ }^{1}$, Prof. Dr N.D.Punjabi ${ }^{2}$, Dr Amit Agarwal ${ }^{3}$ \\ 1,2,3 MGM Medical College Indore, India \\ Email: 'anuvron@gmail.com,2drndpunjabi@gmail.com,3dramitagarwal@yahoo.com
}

\begin{abstract}
The aim was to evaluate any significant correlation between elevated serum uric acid levels and prognosis of patients with acute myocardial infarction primarily short term mortality.

Methods- In this tertiary centre based prospective study 100 new cases of acute MI were divided into various subcategories using Killip classification . Serum uric acid levels were measured on day 0, 3 and 7.Serum uric acid and Killip class were compared on day 0,3 and 7 to assess the prognosis.

Results: Majority of the patients were in the age group of 51-60 years, who accounted for 37 cases i.e. 37\% of total cases. In our study out of 100 patients 70 (70\%) patients were males whereas $30(30 \%)$ were female patients. Majority of patients (45\%) had BMI in the range of $30-34.9 \mathrm{~kg} / \mathrm{cm}^{2} .49 \%$ patients were diabetics with 33 males and 16 females, and $41 \%$ were hypertensive with 27 males and 14 females. History of smoking was present in 59\% patients. Previous history of stroke was observed in $6 \%$ patients with 4 males and 2 females. Mean uric acid level in patients on day 0 belonging to Killip class I was $4.4 \mathrm{mg} / \mathrm{dl}$ compared to 7.01 in Killip class II ,8.29 in Killip class III and 9.87 in Killip class IV. Mean serum uric acid levels on day 7 in patients with Killip class I is 4.67 and those with Killip class II is $6.62 \mathrm{mg} / \mathrm{dl}$.Of the 100 patients, six expired during hospital stay and all 6 belonged to higher Killip class with serum uric acid levels in the highest quartile.
\end{abstract}

Conclusion- Hyperuricemia is an indicator of poor prognosis in acute MI. Serum uric acid can be used as a marker of short term mortality in acute myocardial infarction.

Keywords- Acute MI,Killip class, Serum uric acid,hyperuricemia, short term mortality, CVD.

\section{INTRODUCTION}

Cardiovascular diseases (CVD) have been the leading cause of morbidity and mortality in India. Recent trends indicate that this group of diseases has escalated to younger age groups also. In India, cardiovascular diseases are significantly increasing in males and females in both urban and rural population $^{1}$. As indicated by the data ${ }^{5}$, the prevalence is now increased in rural areas also other than the clichéd urban areas indicating that as the disease matures and gets a stronger grip in the country, it will percolate to all categories of the population affecting the whole society. There is an increasing trend for reversal in the socioeconomic gradient for CVD, with the poor and disadvantaged having equal and sometimes higher burden of CVD and its risk factors ${ }^{19}$. This could be due to the change in lifestyle, the pattern of dietary habits, lack of health care facilities etc. in the lower strata. In 1990, there were an estimated 1.17 million deaths from 
CVD in India ${ }^{3}$. In addition to the high rate of CVD mortality in the Indian subcontinent, CVD manifests almost $10 \mathrm{yr}$ earlier on average in this region as compared to the rest of the world ${ }^{4}$.

Uric acid is the final breakdown product of purine degradation in humans. Urates, the ionised form of uric acid, predominate in plasma extracellular fluid and synovial fluid, with $98 \%$ existing as monosodium urate at $\mathrm{pH}$ 7.4. In addition to the risk for gout and nephrolithiasis, there is increasing evidence that hyperuricemia, directly or indirectly may also be involved in the pathogenesis of CVD ${ }^{5}$. URIC ACID AND OXIDATIVE STRESS ${ }^{20}$-SUA in the early stages of atherosclerotic process is known to act as an antioxidant, but unfortunately, later in the atherosclerotic process with elevated serum uric acid levels, the previously antioxidant becomes pro-oxidant ${ }^{6}$.

URIC ACID AND INFLAMMATION- Xanthine oxidase, the rate limiting enzyme for synthesis of uric acid, has been found localised in endothelial cells and smooth muscle cells of arteries. The resultant uric acid results in free radial injury to the vessel wall and contributes to development of degenerative vascular disease as well as worsening of acute thrombosis ${ }^{7}$.

The aim of this study is to perform detailed clinical workup and record conventional risk factors of CVD among the 100 cases of acute MI. To estimate serum uric acid levels on day 0 , and 7 and correlate these values with Killip class of patients to determine significant correlation between serum uric acid and prognosis.

\section{MATERIALS AND METHODS}

Study was prospective type conducted in MGM Medical College, Indore between March 2015 to August 2015. The study protocol was approved by M.G.M medical college ethics committee and written informed consent was obtained from all subjects prior to participation.

A total of 100 patients of acute MI admitted to the ICCU, Department of Medicine were included in the study after applying the below mentioned criteria.
INCLUSION CRITERIA-

1) Age $>/=18$ yrs

2) All new cases of acute MI patients having -acute chest pain within $12 \mathrm{hrs}$ of presentation with ECG and TropI suggestive of STEMI or NSTEMI.

\section{EXCLUSION CRITERIA-}

1. Patients with atypical chest pain.

2. Patients with unstable angina.

3. Patients with psychosomatic illness, panic disorder, hysterical patients.

4. Patients with chronic kidney disease, gout or haematological malignancy.

5. Patients on drugs such as high dose salicylates, ethambutol, pyrazinamide, chlorthiazide etc.

\section{METHODOLOGY OF DATA COLLECTION}

1. Information was collected and workup of the cases was done as per standard proforma.

2. Relevant clinical workup including detailed history, general and physical examination, serial ECGs and relevant laboratory investigations were carried out in these patients.

3. Appropriate treatment was administered including thrombolysis, anticoagulation etc. as per standard ICCU treatment protocol, modified based on condition of patient.

\section{INVESTIGATIONS}

1. CBP including $\mathrm{Hb} \%$, TLC, DLC etc.

2. Baseline and subsequent serial ECGs.

3. 2D Echo Doppler

4. Random Blood Sugar/Urea/S.Creatinine

5. Serum uric acid on day 0,3 and 7 .

6. Trop I on admission

7. Lipid profile

Statistical methods applied in this study are:

1. Cross tabs procedure (Contingency coefficient test)

2. ANOVA-Analysis of variance-two way.

3. Frequencies and percentages.

4. Descriptive statistics. 


\section{RESULTS}

Table 1-Age distribution of 100 cases of acute MI

\begin{tabular}{|l|l|l|}
\hline Age group & No. of cases & Percentage \\
\hline$<40$ & 11 & 11.00 \\
\hline $41-50$ & 18 & 18.00 \\
\hline $51-60$ & 37 & 37.00 \\
\hline $61-70$ & 23 & 23.00 \\
\hline $71+$ yrs & 11 & 11.00 \\
\hline Total & 100 & 100.00 \\
\hline
\end{tabular}

Table 2 - Sex distribution of study population $(\mathrm{n}=100)$

\begin{tabular}{|l|l|l|}
\hline \multicolumn{1}{|c|}{ Sex } & No. of cases & Percentage \\
\hline Male & 70 & $70 \%$ \\
\hline Female & 30 & $30 \%$ \\
\hline Total & 100 & $100 \%$ \\
\hline
\end{tabular}

Table 3 - BMI of study population

\begin{tabular}{|l|l|l|}
\hline BMI & Frequency & Percentage \\
\hline$<18.5$ & 0 & $0 \%$ \\
\hline $18.6-24.9$ & 11 & $11 \%$ \\
\hline $25-29.9$ & 42 & $42 \%$ \\
\hline $30-34.9$ & 45 & $45 \%$ \\
\hline$>35$ & 2 & $2 \%$ \\
\hline Total & 100 & $100 \%$ \\
\hline
\end{tabular}

Table 4 - Thrombolysis in study population

\begin{tabular}{|l|l|l|l|l|l|}
\hline Thrombolysis & Male & $\%$ & Female & $\%$ & Total \\
\hline No & 16 & 22.86 & 8 & 26.67 & 24 \\
\hline Yes & 54 & 77.14 & 22 & 73.33 & 76 \\
\hline Total & 70 & 100.00 & 30 & 100.00 & 100 \\
\hline
\end{tabular}

Table 5- Comparison of male and female with different risk factors

\begin{tabular}{|l|l|l|l|l|l|l|}
\hline Factors & $\mathrm{M}$ & $\mathrm{F}$ & Total & \%age & $\begin{array}{l}\text { Chi- } \\
\text { square }\end{array}$ & p-value \\
\hline Diabetes & 33 & 16 & 49 & 49 & 0.3190 & 0.5720 \\
\hline HTN & 27 & 14 & 41 & 41 & 0.5630 & 0.4530 \\
\hline Stroke & 4 & 2 & 6 & 6 & 0.0330 & 0.8550 \\
\hline Smoking & 56 & 3 & 59 & 59 & 42.113 & 0.00001 \\
\hline Alcohol & 20 & 0 & 20 & 20 & 10.6070 & 0.0010 \\
\hline
\end{tabular}

Table 6- Comparison of day0, day 3 and day 7 with Killip class by Wilcox matched pairs test

\begin{tabular}{|l|l|l|l|}
\hline Killip class & \multicolumn{1}{|c|}{ Day 0 } & \multicolumn{1}{c|}{ Day 3 } & \multicolumn{1}{c|}{ Day 7 } \\
\hline Death & 0 & 0 & 6 \\
\hline Class 1 & 57 & 65 & 89 \\
\hline Class 2 & 16 & 22 & 5 \\
\hline Class 3 & 14 & 6 & 0 \\
\hline Class 4 & 13 & 7 & 0 \\
\hline Total & 100 & 100 & 100 \\
\hline
\end{tabular}

Table 7- Comparison of Killip classes with serum Uric acid at day 0 by ANOVA (analysis of variance) test

\begin{tabular}{|l|l|l|}
\hline KILLIP class & Mean & Std. Deviation \\
\hline Class 1 & 4.40 & 0.78 \\
\hline Class 2 & 7.01 & 1.12 \\
\hline Class 3 & 8.29 & 0.50 \\
\hline Class 4 & 9.87 & 0.44 \\
\hline Total & 6.07 & 2.22 \\
\hline F-value & 236.2100 & \\
\hline p-value & $0.00001^{*}$ & Pair-wise comparisons by Tukeys multiple posthoc procedure \\
\hline Class 1 vs Class 2 & $\mathrm{p}=0.0001^{*}$ \\
\hline Class 3 vs Class 3 & $\mathrm{p}=0.0001^{*}$ \\
\hline Class 1 vs Class 4 & $\mathrm{p}=0.0001^{*}$ \\
\hline Class 1 vs Class 3 & $\mathrm{p}=0.0002^{*}$ \\
\hline Class 1 vs Class 4 & $\mathrm{p}=0.0001^{*}$ \\
\hline Class 1 vs Class 4 & $\mathrm{p}=0.0001^{*}$ \\
\hline
\end{tabular}

Table 8- Serum Uric acid distribution into quartiles on day 0 vs Killip class

\begin{tabular}{|l|l|l|l|l|l|}
\hline \multicolumn{6}{|c|}{ URIC ACID LEVELS AND KILLIP CLASS ON DAY 0 } \\
\hline & $\begin{array}{l}<4.0 \\
\mathrm{mg} / \mathrm{dl}\end{array}$ & $\begin{array}{l}4.1- \\
5.5 \mathrm{mg} / \mathrm{dl}\end{array}$ & $\begin{array}{l}5.6-7.0 \\
\mathrm{mg} / \mathrm{dl}\end{array}$ & $\begin{array}{l}>7 \\
\mathrm{mg} / \mathrm{dl}\end{array}$ & Total \\
\hline $\begin{array}{l}\text { Killip } \\
\text { class-1 }\end{array}$ & 17 & 36 & 4 & 0 & 57 \\
\hline $\begin{array}{l}\text { Killip } \\
\text { class-2 }\end{array}$ & 0 & 1 & 5 & 10 & 16 \\
\hline $\begin{array}{l}\text { Killip } \\
\text { class-3 }\end{array}$ & 0 & 0 & 0 & 14 & 14 \\
\hline $\begin{array}{l}\text { Killip } \\
\text { class-4 }\end{array}$ & 0 & 0 & 0 & 13 & 13 \\
\hline & 17 & 37 & 9 & 37 & 100 \\
\hline
\end{tabular}

Table 9- Comparison of Killip classes with serum Uric acid at day 3 by ANOVA (analysis of variance) test

\begin{tabular}{|l|l|l|}
\hline KILLIP class & Mean & Std. Deviation \\
\hline Class 1 & 4.46 & 0.79 \\
\hline Class 2 & 7.09 & 0.89 \\
\hline Class 3 & 8.53 & 0.70 \\
\hline Class 4 & 9.43 & 0.80 \\
\hline Total & 5.63 & 1.88 \\
\hline F-value & 146.3145 & \\
\hline $\mathrm{p}$-value & $0.00001^{*}$ \\
\hline Pair-wise comparisons by Tukeys multiple posthoc procedure \\
\hline Class 1 vs Class 2 & $\mathrm{p}=0.0001^{*}$ \\
\hline Class 1 vs Class 3 & $\mathrm{p}=0.0001^{*}$ \\
\hline Class 1 vs Class 4 & $\mathrm{p}=0.0001^{*}$ \\
\hline Class 2 vs Class 3 & $\mathrm{p}=0.0002^{*}$ \\
\hline Class 2 vs Class 4 & $\mathrm{p}=0.0001^{*}$ \\
\hline Class 3 vs Class 4 & $\mathrm{p}=0.2000$ \\
\hline
\end{tabular}


Table 10- Serum Uric acid distribution into quartiles on day 3 vs Killip class

\begin{tabular}{|l|l|l|l|l|l|}
\hline \multicolumn{6}{|c|}{ URIC ACID LEVELS AND KILLIP CLASS ON DAY 3 } \\
\hline & $\begin{array}{l}<4.0 \\
\mathrm{mg} / \mathrm{dl}\end{array}$ & $\begin{array}{l}4.1- \\
5.5 \mathrm{mg} / \mathrm{dl}\end{array}$ & $\begin{array}{l}5.6-7.0 \\
\mathrm{mg} / \mathrm{dl}\end{array}$ & $\begin{array}{l}>7 \\
\mathrm{mg} / \mathrm{dl}\end{array}$ & Total \\
\hline $\begin{array}{l}\text { Killip } \\
\text { class-1 }\end{array}$ & 20 & 43 & 2 & 0 & 65 \\
\hline $\begin{array}{l}\text { Killip } \\
\text { class-2 }\end{array}$ & 0 & 2 & 7 & 13 & 22 \\
\hline $\begin{array}{l}\text { Killip } \\
\text { class-3 }\end{array}$ & 0 & 0 & 0 & 6 & 6 \\
\hline $\begin{array}{l}\text { Killip } \\
\text { class-4 }\end{array}$ & 0 & 0 & 0 & 7 & 7 \\
\hline & 20 & 45 & 9 & 26 & 100 \\
\hline
\end{tabular}

Table 11- Comparison of Killip classes with serum uric acid at day 7 by $\mathrm{t}$ test

\begin{tabular}{|l|l|l|}
\hline Killip class & Mean & Standard deviation \\
\hline Class 1 & 4.67 & 0.80 \\
\hline Class 2 & 6.62 & 1.01 \\
\hline Total & 4.7 & 1.00 \\
\hline T-value & \multicolumn{2}{|c|}{-4.7053} \\
\hline p-value & \multicolumn{2}{|c|}{$0.00001^{*}$} \\
\hline
\end{tabular}

Table 12- Association between Killip classes at day 0 with status of mortality

\begin{tabular}{|l|l|l|l|}
\hline Killip class day 0 & Alive & Death & Total \\
\hline Class 1 & 57 & 0 & 57 \\
\hline Class 2 & 16 & 0 & 16 \\
\hline Class 3 & 14 & 0 & 14 \\
\hline Class 4 & 7 & 6 & 13 \\
\hline Total & 94 & 6 & 100 \\
\hline \multicolumn{4}{|l|}{ Chi-square $=42.7173 \mathrm{p}=0.00001^{*}$} \\
\hline
\end{tabular}

Table 14- Association between Killip classes at day 3 with status of mortality

\begin{tabular}{|l|l|l|l|}
\hline Killip class day 3 & Alive & Death & Total \\
\hline Class 1 & 65 & 0 & 65 \\
\hline Class 2 & 22 & 0 & 22 \\
\hline Class 3 & 4 & 2 & 6 \\
\hline Class 4 & 3 & 4 & 7 \\
\hline Total & 94 & 6 & 100 \\
\hline \multicolumn{4}{|l}{ Chi-square $=45.9643$} \\
$\mathrm{p}=0.00001^{*}$ \\
\hline
\end{tabular}

$*_{p}<0.05$

\section{Discussions}

Kojima et al ${ }^{8}$ in 2005 \& M Y Nadkar et al ${ }^{9}$ in 2008 showed that SUA correlates with Killip Class. We thus used these studies as reference to assess this tool of combining Killip Class with SUA levels as a prognostic indicator in patients with AMI. This study was done in 100 patients with AMI admitted to ICCU wards / Medicine Department of MGMMC $\& \mathrm{MYH}$, Indore. These patients were assessed for uric acid and Killip class on day 0, day 3, day 7 of admission.

Total 100 patients were enrolled in the study, age of the patients varied from 29 years to 75 years .Mean age of patients was $54.9 \pm 11.59$ yrs. This correlated with other previous studies by $\mathrm{S}$ Agarwal et $\mathrm{al}^{10}$, Gandaiah et $\mathrm{al}^{11}, \mathrm{M}$ Y Nadkar et $\mathrm{al}^{9}$. In our study out of 100 patients enrolled $70 \%$ patients were male, $30 \%$ patients were female. Majority of the patients were male .This finding is in concurrence with other previous studies ${ }^{15}$. Previous studies have also shown that Myocardial infarction is common in males compared to females. It was found that there was no significant difference in uric acid levels with regards to sex of the patients (Chi-square $=5.2631 \mathrm{P}$ $=0.2612$ ). However in the study done by Dae Woo Hyun et al in 2007 showed that SUA levels were better predictor of cardiovascular events in male patients with CAD than females. This was proposed to be due to the protective action of estrogen up to menopause following which uric acid levels rise in females also. This can probably explain the gender insignificance in our study as majority of the women who presented with AMI were postmenopausal. In our study we found statistically significant difference in uric acid levels between hypertensives and non hypertensives .This correlates with Kojima et $\mathrm{al}^{8}$ Sokhanvar et al ${ }^{12}$ study. This finding did not correlate with other studies like MY Nadkar et al, Shetty et $\mathrm{al}^{13}$, S Agarwal et $\mathrm{al}^{10}$ who found no statistical significance in uric acid levels between hypertensives and non hypertensives. In our study $49 \%$ patients were diabetics. It was found that hyperuricemia is significantly associated with diabetes mellitus. $(\mathrm{t}=4.1682, \mathrm{p}=0.0001$ on day 1 ; $\mathrm{t}=3.1784, \mathrm{p}=0.0020$ on day 3 and $\mathrm{t}=3.5805$, $\mathrm{p}=0.0006$ on day 7). This is in agreement with findings of Safi et $\mathrm{al}^{14}$ which showed significant relationship between diabetes and serum uric acid level. This is contrary to studies done by Kojima et al ${ }^{8}$, M Y Nadkar et $\mathrm{al}^{9}$, Gandaiah et $\mathrm{al}^{11}$ found no significant difference in uric acid levels. In our study 56 patients had history of smoking and 3 patients had history of tobacco chewing. We found statistically significant difference in uric acid levels 
between smokers \& nonsmokers (chi square 42.1130, $\left.\mathrm{p}=0.00001^{*}\right)$.In our study the mean uric acid on the day of admission in males was $6.13 \pm 2.3 \mathrm{mg} / \mathrm{dl}$ and $5.94 \pm 1.96 \mathrm{mg} / \mathrm{dl} \quad(\mathrm{p}=0.6943)$. There is no statistical difference between the mean uric acid levels of males and females. This finding correlates with Gandaiah et $\mathrm{al}^{11}$ \& Shetty et $\mathrm{al}^{13}$.Mean uric acid levels were higher on day of admission in our study as compared to mean uric acid level on day7.This finding correlates with Shetty et $\mathrm{al}^{13}$ and $\mathrm{S}$ Agarwal et $\mathrm{al}^{10}$, however it does not correlate with M Y Nadkar et $\mathrm{al}^{9}$.It can be explained that in our study on day 7 all patients belonged to Killip class 1 or 2,hence lower mean uric acid levels.In our study on day 0, 57\% belonged to Killip class I, $16 \%$ belonged to Killip class II, $14 \%$ belonged to Killip class III \&13\% belonged to Killip class IV. This finding correlates with findings in with M Y Nadkar et $\mathrm{al}^{9}$ \& Gandaiah et $\mathrm{al}^{11}$, herein on day of admission majority of patients belonged to Killip class I.We found that on all days, with increasing Killip class there is increasing mean uric acid level. We found statistically significant difference $(\mathrm{p}<0.00001)$ on day0,3 and 7.Out of 100 patients included in the study 6 patients expired during 7 day follow up all of whom belonged to Killip class IV on admission. These patients expired between day 3 and 7, their mean uric acid was $>9 \mathrm{mg} / \mathrm{dl}$. Thus in our study mortality was high in patients with higher Killip class with higher Killip classes having higher mean uric acid levels. Therefore it shows that serum uric acid concentration is significantly correlated with Killip class and mortality. These findings correlate with previous studies i.e.M Y Nadkar et $\mathrm{al}^{9}$, Gandaiah et $\mathrm{al}^{11}$, Shetty et $\mathrm{al}^{13} \& \mathrm{~S}$ Agarwal et $\mathrm{al}^{10}$.

\section{CONCLUSION}

From our study, we conclude that serum uric acid levels are correlated with Killip class and patients with higher Killip class have higher SUA levels in acute MI. Hyperuricemia is an indicator of poor prognosis in acute MI. Serum UA can be used as a marker of short term mortality in acute MI.SUA levels were elevated in systemic hypertension and
DM patients with acute MI in our study. Serum uric acid is an economical biomarker that is readily, quickly and reliably obtainable and thus along with Killip's classification should be considered for risk stratification in patients with AMI. However, this study is limited by relatively small study population and needs to be supplanted by other similar studies.

\section{REFERENCES}

1. Chauhan S., \& Aeri B. T., Prevalence of cardiovascular disease in India and its economic impact-A review. International Journal of Scientific and Research Publications, 2012.

2. Gupta R. Burden of coronary heart disease in India. Indian Heart Journal. 2005; 57: 632-8.

3. Murray CJ, Lopez AD, editors. The global burden of disease: A comprehensive assessment of mortality and disability from diseases, injuries, and risk factors in 1990 and projected to 2020. Cambridge, MA: Harvard University Press; 1996.

4. Goyal, A., \& Yusuf, S. (2006). The burden of cardiovascular disease in the Indian subcontinent. Indian J Med Res, 124(3), 235-244.

5. Hediger, M. A., Johnson, R. J., Miyazaki, H., \& Endou, H. (2005). Molecular physiology of urate transport. Physiology, 20(2), 125-133

6. Niskanen LK, Laaksonen DE, Nyyssonen K, Alfthan G, Lakka HM, Lakka TA, Salonen JT (2004): Uric acid level as a risk factor for cardiovascular and all cause mortality in middle-aged men: a prospective cohort study. Arch Intern Med 164:1546-51

7. Eugene Braunwald ST segment elevation myocardial infarction chapter 54. Braun Wald textbook of cardiovascular medicine $9^{\text {th }}$ edition 2009 Mc Graw Hill.

8. Kojima, S., Sakamoto, T., Ishihara, M., Kimura, K., Miyazaki, S., Yamagishi, M.,... \& Ogawa, H. (2005). Prognostic usefulness of serum uric acid after acute myocardial 
infarction (the Japanese Acute Coronary Syndrome Study).The American journal of cardiology, 96(4), 489-495

9. Nadkar, M. Y., \& Jain, V. I. (2008). Serum uric acid in acute myocardial infarction. JAPI, 56(10), 759-762

10. Agrawal, S., Aundhkar, S. C., Patange, A., Panpalia, N. G., Jain, S., \& Garg, R.(2014). Evaluate the Role of Serum Uric Acid in Acute Myocardial Infarction as a Prognostic Marker. International Journal of Health Sciences and Research (IJHSR), 4(5), 120128.

11. Gandiah, P., Venkateshwarlu, N., Naveen Kumar, M., Indira, G., \& Sivarajappa, P. (2013). Serum Uric acid Estimation in Acute Myocardial Infarction-A Prognostic Indicator

12. Sokhanvar, S., \& Maleki, A. (2007). Blood Uric Acid Levels According to Cardiovascular Disease Risk Factors in Patients with Myocardial Infarction. IRANIAN HEART JOURNAL (IHJ).

13. Shetty, S., Rao, A. H., \& AK, S. K. (2013). Serum Uric Acid as a prognostic biomarker $\&$ its correlation with Killip Class in Acute Myocardial Infarction. International Journal of Biomedical Research, 4(7), 312-316

14. Omidvar, B., Ayatollahi, F., \& Alasti, M. (2012). The prognostic role of serum uric acid level in patients with acute ST elevation myocardial infarction. Journal of the Saudi Heart Association, 24(2), 73-78.

15. Car, S., \& Trkulja, V. (2009). Higher serum uric acid on admission is associated with higher short-term mortality and poorer long-term survival after myocardial infarction: retrospective prognostic study. Croatian medical journal,50(6), 559-566.

16. Bae, M. H., Lee, J. H., Lee, S. H., Park, S. H., Yang, D. H., Park, H. S., ... \& Chae, S. C. (2010). Serum uric acid as an independent and incremental prognostic marker in addition to $\mathrm{N}$-terminal pro-B-type natriuretic peptide in patients with acute myocardial infarction. Circulation journal: official journal of the Japanese Circulation Society, 75(6), 1440-1447.

17. Trkulja, V., \& Car, S. (2012). On-admission serum uric acid predicts outcomes after acute myocardial infarction: systematic review and metaanalysis of prognostic studies. Croatian medical journal, 53(2), 162-172

18. Chen L., Xian-Tun L., et al. Serum uric acid in patients with acute ST-elevation myocardial infarction. World J Emerg Med. 2012; 3(1): 35-39

19. Conen D, Wietlisbach V, Bovet P, Shamlaye C, Riesen W, Paccaud F, Burnier M (2004): Prevalence of hyperuricemia and relation of serum uric acid with cardiovascular risk factors in a developing country. BMC Public Health 4: 9.

20. Sautin YY, Nakagawa T, Zharikov S, Johnson RJ (2007): Adverse effects of the classic antioxidant uric acid in adipocytes: NADPH oxidase - mediated oxidative/ nitrosative stress. Am J Physiol Cell Physiol 293:C584-96.

21. Agrawal S., Aundhkar C.S., Patange A. , Panpalia G.N., et al. Evaluate the Role of Serum Uric Acid in Acute MI as a prognostic marker. IJHSR : 2014; 4 (5)

22. Surya, D. (2012). Serum Uric Acid As An Independent Predictor of Cardiovascular Event In Patients With Acute ST Elevation Myocardial Infarction. Journal of Clinical \& Experimental Cardiology

23. Glantzounis GK, Tsimoyiannis EC, Kappas AM, Galaris DA (2005): Uric Acid and Oxidative Stress. Curr Pharm Des 11:414551. 